Кемеровского государственного университета культуры и искусств. - 2011. - № 14. С. 57-67. 12. Проскурякова Л. А. Здоровьесбережение в системе высшего образования / Л. А. Проскурякова // Высшее образование сегодня. - 2010. - № 6. С. 80-83. 13. Селезнева Н. А. К вопросу о социально-психологической адаптации студентов к условиям учебной работы в вузе/ Н. А. Селезнева // Ученые записки Казанской государственной академии ветеринарной медицины им. Н. Э. Баумана. 2010. - № 202. - С. 331-336. 14. Югова Е. А. Технологии формирования здоровьесберегающей компетентности у студентов: [монографія]/ Е. А Югова; рец.: С. Г. Махнева, Л. Г. Петрова; Рос. гос. проф.-пед. ун-т. - Екатеринбург: Издательство РГППУ, 2012. - 116 с. 15. Шатрова Е. А. Моделирование здоровьесберегающей компетентности педагога/ Межвуз. науч. конф.-семинар молодых ученых по результатам исследований в области психологии, педагогики и социологии (25 декабря 2009 г., г. Красноярск): сб. тр.: в 3 ч. Ч.3. / под общ. ред. Я. А. Максимова; Научноинновационный центр - Красноярск, 2010. С. 124. 16. Устав (Конституция) Всемирной Организации Здравоохранения// ВОЗ. Основные документы. 39-е издание; [пер. с англ.] - М. : Медицина, 1995. - 208 с.

УДК 378.147:371.38.

Віктор Мадзігон

\title{
ТЕОРЕТИКО-МЕТОДИЧНІ ЗАСАДИ ПІДГОТОВКИ ПІДПРИЕМЦІВ У СИСТЕМІ ЕКОНОМІЧНОЇ ОСВІТИ
}

Мадзігон В. В. Теоретико-методичні засади підготовки підприємців у системі економічної освіти.

У статті висвітлюється актуальна проблема необхідності на сучасному етапі підготовки підприємців у системі безперервної економічної освіти, у навчанні учнівської та студентської молоді. Набуті знання 3 економічних дисциплін вони зможуть використовувати у практичній діяльності на ринку праці в різних галузях суспільних потреб задля піднесення добробуту держави й суспільства.

Ключові слова: ринкова економіка, економічна освіта, підприємництво, підприємці, фахова компетентність, ринок праці.

Мадзигон В. В. Теоретико-методические основы подготовки предпри-нимателей в системе экономического образования.

В статье освещается актуальная проблема необходимости на современном этапе подготовки предпринимателей в системе непрерывного экономического образования, в обучении школьников и студенческой молодежи. Приобретенные знания экономических дисциплин они смогут использовать в практической деятельности на рынке труда в различных отраслях общественных потребностей для повышения благосостояния государства и общества.

Ключевые слова: рыночная экономика, экономическое образование, предпринимательство, предприниматели, профессиональная компетентность, рынок труда.

Madzygon V. V. Theoretical and methodological basis of training of entrepreneurs in the system of economical education.

The article observe an important issue of current interest of the necessity of training of entrepreneurs in the system of continuous economical education, of education of students; 
those knowledge of economical disciplines could be used in practical activities at the labor market, in different fields of social needs for increasing of the wealth of state and society.

Key words: market economy, economical education, entrepreneurship, entrepreneurs, professional competence, labor market.

В умовах формування ринкового господарства, інституціональних змін в економіці України, радикальних змін у відносинах власності проблема становлення і розвитку підприємництва набуває неабиякого значення. Актуальність дослідження проблем розвитку та становлення підприємництва посилюється також і тим, що повільність та суперечливість просування України шляхом ринкових реформ значною мірою зумовлені саме недооцінкою ролі та значення всебічної підготовки в системі освіти до підприємницької діяльності випускників ВНЗ як структуроутворювального елемента ринкової економіки.

Перші роки проведення економічних реформ в Україні довели, що організація виробництва, раціонального використання виробничих ресурсів та споживання неможливі без послідовного переходу до ринкової економіки та підготовки для ринку праці кваліфікованих підприємців, менеджерів, які б могли своїми високими професійними компетенціями сприяти розвитку та становлення виробництва, сфери послуг у всіх видах людської діяльності [4].

Окресленій проблемі присвячено значну кількість науково-методичної літератури, яка висвітлює питання підприємництва як напрям людської діяльності, зокрема працы таких дослыдникыв: 3. Варналій, В. Сизоненко [1], М. Вачевський, В. Мадзігон, [2], Й. Петрович, Г. Захарчин [9], І. Михасюк, І. Бернадський [8], В. Куликов [4; 5; 6] та інших авторів, використовуються в навчальному процесі.

Мета статmi - обгрунтувати необхідність вивчення підприємницької діяльності у процесі безперервної економічної освіти. Економічна підготовка передбачає засвоєння системи знань, починаючи в загальноосвітній школі, професійно-навчальному закладі і продовжуючи у ВНЗ, де студент зможе поступово отримати високий рівень якості освіти та належний рівень професійних компетенцій, як цього вимагають нормативи Болонського процесу, довгострокової політики, спрямованої на розвиток суспільства, подальшого процвітання держави та розвитку людського потенціалу.

Важливим завданням, на розв'язання якого спрямовані зусилля уряду України, є удосконалення безперервної впродовж життя системи освіти. Об'єктивним є факт, що що світове співтовариство зазнає стрімких змін. Зростає потреба в адаптації різних систем вищої освіти, їх конкурентоспроможності, а також можливості відповідати належним чином на виклики глобалізації [7]. У цьому аспекті і полягає сутність нашого дослідження - підготовки на високому професійно-фаховому рівні підприємців до сучасних конкурентних умов ринкової економіки до ринку праці.

Одним з основних напрямків, що забезпечують динамізм у розвитку економіки і виведенню їі на ринковий шлях, є активізація підприємницької діяльності та підготовка підприємців у системі вивчення економіки, маркетингу i підприємництва, а у професійно-технічних навчальних закладах - вивчення спеціалізації за класифікатором професій, який призначений для застосування центральними органами виконавчої влади, органами місцевого самоврядування, роботодавцями України, всіма об'єктами господарювання.

Підприємництво - це здійснення сміливих, важливих i складних проектів. Підприємництво - це готовність взяти на себе ризик, пов'язаний із реалізацією нових ідей. Саме підприємництво, яке асоціюється 3 поняттями «динамізм», «ініціатива», «сміливість», перетворює в реальність нові цікаві ідеї [5]. 
Підприємницька діяльність - це передусім інтелектуальна діяльність енергійної та ініціативної людини, яка володіє повністю або частково будь-якими матеріальними цінностями і використовує їх для організації бізнесу та управління ним.

Задля розв’язання проблем економічного і соціального розвитку України на сучасному етапі становлення ринкової економіки слід посилити увагу держави до розвитку підприємницької діяльності, насамперед, малого підприємництва, формування відповідної державної політики щодо підтримки освітніх програм підготовки підприємців у закладах безперервної системи освіти, учнівської та студентської молоді.

Що таке підприємництво? Хто такий підприємець? Ці та інші запитання виникають у молоді, яка після закінчення навчання хоче розпочати свою справу на основі власних або відомих ідей, реалізація яких може принести у майбутньому вигоду.

На перше з поставлених запитань можлива така відповідь. 3 переходом України до ринку, підприємництво розглядається як організаційно-економічне і соціальнопсихологічне явище, що характеризується науково-технічним, комерційним, організаційним і винахідницьким новаторством [6].

Як відзначають М. Вачевський та В. Мадзігон [2], разом 3 такими факторами виробництва, як земля, праця та капітал, економіка вивчає також підприємництво. Наявність вільного підприємництва є однією із визначальних ознак ринкової економіки. Тема «Підприємництво» розкриває сутність цієї категорії, з'ясовує умови та функції підприємницької діяльності, характеризує основні їі форми.

Отже, підприємництво - це самостійна, ініціативна, систематична діяльність на власний ризик із виробництва продукції, надання послуг і торгівлі задля одержання прибутку.

У сучасних джерелах інформації науковці висловлюють припущення, що «підприємництво» і «бізнес» - тотожні поняття. Але підприємництво - особливий вид бізнесу. Практична мета підприємництва - вилучення не просто прибутку, а отримання надприбутку, що і відрізняє підприємницьку діяльність від бізнесу, який має завдання отримати тимчасову вигоду.

Зміст підприємницької діяльності складають такі види, як виробнича, комерційна, торгівельна, закупівельна, посередницька, інвестиційна, консультаційна, фінансова, науково-навчальна, а також надання послуг юридичних, навчальних, лікувальних, туристичних, сфери харчування, торгівлі та інших видів діяльності.

Підприємницька діяльність грунтується на мобілізації коштів (фінансів), трудових, матеріальних, інформаційних та інтелектуальних ресурсів (базова основа); організації виробництва, матеріально-технічного забезпечення і збуту, маркетингу та реклами (організаційна основа); новаторстві, що включає винахідництво, використання нових ідей на творчій основі і кон'юнктурі ( творча основа). Більшість видів підприємницької діяльності відноситься до так званого малого підприємництва, яке має розвиток у всіх сферах людської діяльності [1].

Названі види підприємницької діяльності вимагають особливої підготовки учнівської та студентської молоді до цієї діяльності, мати відповідні професійні компетенції до певного виду діяльності, знання 3 економіки, менеджменту та маркетингу, фінансово-кредитної системи, суті і функції грошей, видів власності в ринковій системі господарювання, економічні основи ціни, значення державного бюджету, системи податків та зборів, банківської системи, нормування праці, видів заробітної плати та іiі сутності, виробництва та споживання, стандартизації, диференціації та якості товару у процесі виробництва, страхової справи та інноваційної діяльності, світового ринкового господарства та глобальних економічних проблем. 
Безперечно важливим є знання, вміння та навички, які молодь набуває в процесі навчання в школі, у професійному середньому закладі та ВНЗ. Набуті знання - основа формування в майбутніх підприємців знань галузей людської діяльності, професійних компетенцій, що пов'язано 3 багатьма чинниками, оскільки підприємницька компетенція дає підстави визначити готовність випускника навчального закладу чи ВНЗ до життя, його подальшого розвитку й активної участі в діяльності суспільства.

I тому підготовка та формування підприємницьких здібностей у майбутніх підприємців уже нині вимагає впровадження у зміст освіти 3 економічних дисциплін введення нових напрямків навчання підприємницької діяльності у тих напрямках, які нами відзначено.

Недооцінку підготовки молоді до підприємницької діяльності та розвитку підприємництва, ігнорування його економічних та соціальних можливостей протягом майже вусіх років незалежності, реформаційних перетворень можна класифікувати як великий стратегічний прорахунок, який також поглибив кризу економіки України.

Аналіз реальних процесів розвитку підприємництва та фахової підготовки підприємців в Україні, реалізації урядових дій щодо його підтримки показує, що головною причиною, яка стримує подальший розвиток підприємництва, $\epsilon$ несформованість у країні ефективної законодавчо закріпленої державної політики розвитку підприємництва. Свідченням неефективності діяльності органів державної влади у сфері розвитку підприємництва в Україні $є$ насамперед зниження темпів зростання кількості діючих малих підприємств та чисельності працюючих в них, посилення процесу «тінізації» суб'єктів малого підприємництва. Цей процес відбувається у зв'язку з великим навантаженням на приватний сектор.

Як може мале підприємництво, що має досить незначний прибуток, сплачувати всі податки і обов'язкові платежі відповідно до чинного законодавства, не порушуючи його? Звичайно, для багатьох з них це реально не можливо. А це призводить до занепаду підприємництва та до значних втрат держави. Єдиним виходом для приватників є або приховування своїх прибутків, тобто ухилення від сплати податків, або (за умови дотримання чинного законодавства) працювати за принципом «що заробив, те й віддав». Зрозуміло, що такий перебіг подій не влаштовує нікого. Тому в цій ситуації важливим завданням держави є допомогти, підтримати та стимулювати малий бізнес.

Розв'язання наявних проблем розвитку підприємництва в Україні потребує нових підходів до сприяння розвитку підприємництва. По-перше, завдання полягає в тому, щоб суттєво підняти роль та місце підприємництва в економічному процесі суспільства, a саме - забезпечити протягом найближчих років у структурі зазначеного сектору зайнятість на рівні 25-30\% дієздатного населення та виробництва до 25\% ВВП.

По-друге, підприємництву треба вчити, починаючи із шкільної парти, професійнотехнічних училищ, яких в Україні нараховується близько 500 закладів, у яких навчаються майже 500 тисяч учнів та слухачів, із них 478 тисяч- це випускники загальноосвітніх шкіл, близько 18 тисяч прийшли за направленням служби зайнятості, близько 5 тисяч працюють на виробництві та підвищують свою кваліфікацію. Щорічно навчальні заклади направляють на виробництво та у сферу послуг більше чверті мільйона випускників, як зазначає В. Кремень [3].

ВН3 забезпечують високий рівень сформованості професійних компетенцій, відповідно, якість освіти і знань, які повинні відповідати вимогам Болонського процесу. Освіта має бути спрямована на повний розвиток особистості, зміцнювати повагу до прав людини, основних свобод та миру, давати змогу усім людям брати активну участь у побудові вільного та рівноправного суспільства. Академічна спільнота є одним із найважливіших органів, які утверджують і переносять 3 покоління в покоління інтелектуальні та культурні цінності. Вищі навчальні заклади мають функції і завдання, як державні, так і міжнаціональні [7]. 
Ця тема є досить актуальною нині. Тому ії дослідженню присвячено дуже багато статей, наукових праць, які висвітлюють специфіку розвитку підприємництва, підготовки до цієї діяльності фахівців із відповідним рівнем професійних компетентностей для їх ефективної професійної діяльності, проблеми фінансового забезпечення, проблеми оподаткування та інших фінансово-економічних аспектів. Але слід зазначити, що значним прорахуванням $\epsilon$ те, що наукові дослідження з проблем оподаткування суб'єктів малого підприємництва переважно зводяться до аналізу положень зарубіжного та вітчизняного або тільки зарубіжного податкового права, їх узагальнення та розробки конкретних пропозицій з вдосконалення податкового законодавства. Тобто вивчається зарубіжний досвід, на основі якого пропонують модель розвитку, системи та принципи оподаткування малого бізнесу нашої країни. Але ж зрозуміло, що нашу країну не можливо порівняти із країнами із високорозвиненою ринковою економікою, а тому й неправильним буде застосування їх моделей. Потрібно вивчити весь процес функціонування цих моделей, специфіку розвитку бізнесу в цих країнах, проаналізувати усі можливі наслідки, позитивні і негативні сторони проведення певної політики в нашій країні, збалансувати потреби держави з потребами малих підприємств.

Однак проблема розвитку приватного сектору економіки й підприємництва вимагає постійного вивчення, удосконалення підходів до цієї діяльності [9].

Реалізації моделі формування професійної фахової компетентності у майбутніх підприємців у процесі безперервної системі освіти потребує наукового управління, використання менеджменту, пристосування до сучасних умов економічної системи, демократизації та гуманізації загальноосвітньої школи. Підвищити навчально-виховний процес на якісно новий рівень не можливо без високого рівня професійної готовності тих, хто безпосередньо запроваджує в життя підприємницьку діяльність. Будь-яка перебудова навчання - процес складний i неоднозначний, зокрема, підхід до розроблення та впровадження в навчальний процес нових програм, підручників, посібників, апробованих технологій навчання. Сучасна освіта у своєму розвитку досягла такого рівня, що потрібен і новий напрямок думок, і новий підхід до навчання на основі нових розробок для підготовки учнівської та студентської молоді до підприємництва, вдосконалення господарської діяльності [8].

Для успішної практичної реалізації будь-якої господарської задачі в умовах ринкової економіки, коли в основу подальшого функціонування різних форм власності покладено розвиток інновацій і вдосконалення господарського механізму, виникає потреба підготовки спеціалістів, готових до роботи в сучасних умовах ринкової конкурентної економіки, а також педагогів із знанням економіки, маркетингу, менеджменту та інших економічних напрямків людської діяльності.

Отже, виникає суперечність між вимогами суспільства та наявним науковим підходом підготовки підприємців - фахівців із відповідним високим рівнем професійних компетентностей щодо діяльності в умовах ринкової економіки.

Для розвитку підприємництва в нових умовах господарювання необхідно ввести цілеспрямовану підготовку молоді в навчальних закладах, збагачуючи іiі знаннями економіки, розвиваючи іiі творчість, які згодом втіляться в основи підприємницької діяльності.

Отже, підприємництво діє в різних сферах виробництва і здійснюється як окремою приватною особою, так і групами людей задля створення матеріальних благ та отримання прибутків. Саме розвиток підприємництва прямо залежить від підготовлених до цієї діяльності фахівців 3 високим рівнем професійної компетенції, без яких неможливе ефективне використання ресурсів та реалізація продукції виробництва. 


\section{Література}

1. Варналій 3. С. Основи підприємницької діяльності. Підручник для учнів 10-11 кл. / 3. С. Варналій, В. О. Сизоненко. - К. : Знання, 2004. - 404 с. 2. Вачевський М. В. Основи економіки. Навч. пос. для 10-11 кл. / М. В. Вачевський, В. М. Мадзігон. - К. : Педагогічна думка, 2007. - 612 с. 3. Кремень В. Г. Освіта у XXI столітті / В. Г. Кремень. Шлях освіти, 2003. - № 2. - С. 2-4. 4. Кулішов В. В. Основи ринкової економіки. / В. В. Кулішов, О. С. Подалка, М. В. Вачевський / за ред. В.В.Кулішова. - Львів: Магнолія, 2013. - 472 с. 5. Кулішов В. В. Економічний довідник підприємця/ В. В. Кулішов. - Львів: Магнолія, 2009. - 162 с. 6. Кулішов В. В. Основи економічної теорії / В. В. Кулішов. - Львів : Магнолія плюс, 2007. - 516 с. 7. Левківський К. М. Збірник нормативних актів щодо Болонського процесу / Уклад.: Левківський К. М., Логвін 3. І., Губерська Н. Л. - К. : ПТЗО, 2008. - 120 с. 8. Михасюк I. Р. Українське підприємництво в умовах глобалізації / I. Р. Михасюк, І. М. Бернадський. - Львів : Видав. центр ЛНУ ім. Івана Франка, 2008. - 56 с. 9. Петрович Й. М. Організація підприємництва в Україні. / Й. М. Петрович, Г. М. Захарчин, А. А. Теребух. - Львів : Оксарт, 2000. -320 c.

Тетяна Мелкумова

\section{ВИВЧЕННЯ ПРИКМЕТНИКІВ НА ЗАНЯТТЯХ З УКРАЇНСЬКОЇ МОВИ ЯК ІНОЗЕМНОЇ НА І КУРСІ}

Мелкумова Т. В. Вивчення прикметників на заняттях $з$ української мови як іноземної на I курсі.

У статті запропоновано низку завдань для актуалізації, поглиблення, систематизації, узагальнення та закріплення знань іноземних студентів I курсу про граматичні категорії прикметників, сполучуваність прикметників з іменниками. Подано методику вивчення розрядів прикметників за значенням і ступенів порівняння якісних прикметників.

Ключові слова: прикметник, тверда група, м’яка група, ступені порівняння.

Мелкумова Т. В. Изучение имён прилагательных на занятиях по украинскому языку как иностранному на I курсе.

В статье предложена серия заданий для актуализации, углубления, систематизации, обобщения и закрепления знаний иностранных студентов I курса о грамматических категориях имён прилагательных. Подана методика изучения разрядов имён прилагательных по значению и степеней сравнения качественных прилагательных.

Ключевые слова: имя прилагательное, твёрдая группа, мягкая группа, степени сравнения.

Melkumova T. W. Studying the adjectives on Ukrainian as foreign language lessons for the first-course students.

The article deals with the set of tasks for actualization, intensification, systematization, generalization and consolidation of foreign students' knowledge about grammar adjective categories and combination of adjectives and nouns. The methods of studying the meaning adjective categories and degrees of comparison of qualitative adjectives are given.

Key words: adjective, hard group, soft group, degrees of comparison. 